\title{
Periphyton metabolism along a nutrient gradient in a desert river (Truckee River, Nevada, USA)
}

\author{
Urs Uehlinger ${ }^{1}$ and James T. Brock ${ }^{2}$ \\ ${ }^{1}$ Department of Limnology, Swiss Federal Institute of Aquatic Science and Technology (Eawag), CH-8600 Dübendorf, \\ Switzerland \\ ${ }^{2}$ Division of Earth and Ecosystem Sciences, Desert Research Institute, Reno, Nevada 89512, USA
}

Received: 29 November 2004; revised manuscript accepted: 5 July 2005

\begin{abstract}
Periphyton metabolism was studied at five sites along a $70 \mathrm{~km}$ unshaded stretch of the Truckee River below the City of Reno, Nevada (USA). Sites differed with respect to concentrations of soluble reactive phosphorus and total dissolved inorganic nitrogen because a water pollution control facility discharged its treated wastewater through a small tributary into the river downstream of site 1 (most upstream located site). Unglazed tiles were incubated at each site from late June to August (summer) and from September to November (autumn) 1986. At the end of each incubation period, oxygen metabolism of the periphyton communities growing on tiles was measured in transparent flow-through respiration chambers for 24 $\mathrm{h}$ under near natural light and temperature conditions. In August, when biomass and metabolism were positively
\end{abstract}

correlated with nitrogen and phosphorus, mean chlorophyll $a$ ranged from 53 (site 1) to $290 \mathrm{mg} \mathrm{chl} a \mathrm{~m}^{-2}$ (site $2,3 \mathrm{~km}$ downstream of the wastewater input). Periphyton gross primary production varied between $3.3 \pm 0.8$ (site 1 ) and $9.1 \pm 1.4 \mathrm{~g} \mathrm{O}_{2} \mathrm{~m}^{-2} \mathrm{~d}^{-1}$ (site 2), and respiration between $2.1 \pm 0.4$ and $10.1 \pm 1.3 \mathrm{~g} \mathrm{O}_{2} \mathrm{~m}^{-2} \mathrm{~d}^{-1}$. P/R ratios ranged from 0.9 at site 2 to 1.8 about $65 \mathrm{~km}$ downstream from the wastewater input. In November, chlorophyll a was significantly higher $\left(99 \pm 29\right.$ to $509 \pm 155 \mathrm{mg}$ chl $a \mathrm{~m}^{-2}$ and gross primary production and respiration on average 50 and $65 \%$ lower, respectively, than in August. Hence, colder temperatures appeared to reduce respiration more than primary production and significantly increased P/R. Neither gross primary production nor respiration were correlated with autumn nutrient concentrations.

Key words. Primary production; community respiration; P/R; biomass; nutrients; chamber method.

\section{Introduction}

Periphyton is the primary autotrophic energy base in open-canopied streams (Minshall, 1978). Apart from light, temperature, nutrients and flow are major determinants controlling periphyton development (Biggs, 1995; Biggs, 1996; Borchardt, 1996; Fisher and Grimm, 1988; Hill, 1996; Uehlinger et al., 1996). Human activities

* Corresponding author e-mails: uehlinger@eawag.ch; Jim.Brock@dri.edu Published Online First: October 18, 2005 (urbanization, agriculture) are typically associated with prolific periphyton accrual as a result of enhanced nutrient input from runoff from fertilized crop land or sewage effluents, and increased light availability due to channel widening and removal of riparian vegetation (Biggs, 1995). Studies relating periphyton biomass and nutrients are numerous and directed to detect nutrient limitation and effects of nutrient enrichment (e.g., Bushong and Bachmann, 1989; Chessman et al., 1992; Pringle, 1987; Pringle and Bowers, 1983), or to describe nutrient-periphyton biomass relationships (e.g., Biggs, 1995; Biggs, 2000; Dodds et al., 2002; Taylor et al., 2004; Welch et 
al., 1988). Investigations on the relationship between periphyton metabolism and nutrients are less common (Guasch et al., 1995), in particular with respect to respiration or the balance between auto- and heterotrophic processes (typically characterized by the $\mathrm{P} / \mathrm{R}$ ratio).

Streams in arid or semi-arid catchments (except from high latitudes or altitude) offer favorable conditions for algal growth, in particular with respect to light and temperature (Fisher et al., 1982; Minshall, 1978). In this environment, periphyton is expected to respond with rapid growth to enhanced nutrient supply unless frequent flooding, drought (zero flow), or low sediment stability limit accrual (Fisher and Grimm, 1988; Grimm and Fisher, 1989; Uehlinger et al., 2002). The focus of this paper is on periphyton metabolism along a $70-\mathrm{km}$ river reach located in a semi-arid environment. This river system is influenced by a nutrient point source (sewage treatment facility) that created a distinct nutrient gradient with concentrations of dissolved inorganic nitrogen and phosphorus constituents varying by 1 to 2 orders of magnitude. Our objective was to assess changes in periphyton biomass and metabolism, including possible changes in the balance between auto- and heterotrophic processes along this nutrient gradient. To elucidate the effect of season on the manifestation of nutrient enrichment, we studied biomass and metabolism in summer and autumn, periods representing contrasting light and temperature conditions.

\section{Methods}

\section{Study system and study design}

The Truckee River flows from the oligotrophic Lake Tahoe (river km 0, $1898 \mathrm{~m}$ a.s.l.) to its terminus, Pyramid Lake (river km 187, $1157 \mathrm{~m}$ a.s.l.) in the Great Basin desert. The flow regime is characterized by high flow in spring and early summer (snowmelt in the Sierra Nevada) and a subsequent constant, managed, low discharge until spring. The base flow period during summer and autumn is maintained by releases from control structures on several lakes and reservoirs. Inter-annual variation in flow patterns is high with annual discharge varying between 2.6 and $70.8 \mathrm{~m}^{3} \mathrm{~s}^{-1}$. Most parts of the study reach (river km 97-166; hereafter, values represent distance from Lake Tahoe) are exposed to direct solar radiation because the active channel is wide ( $>20 \mathrm{~m}$ ) and riparian tree vegetation is scattered or widely lacking. Bed sediments consist of sand, gravel, and at a few sites, cobble. Steamboat Creek, the recipient of the treated sewage from the cities of Reno and Sparks (combined population $\sim 220,000$ in 1986), enter the river at river $\mathrm{km} \mathrm{101}$, and considerably increase concentrations of major nutrients. Three years after the end of this study about $75 \%$ of the inorganic nutrient load to the river was removed through

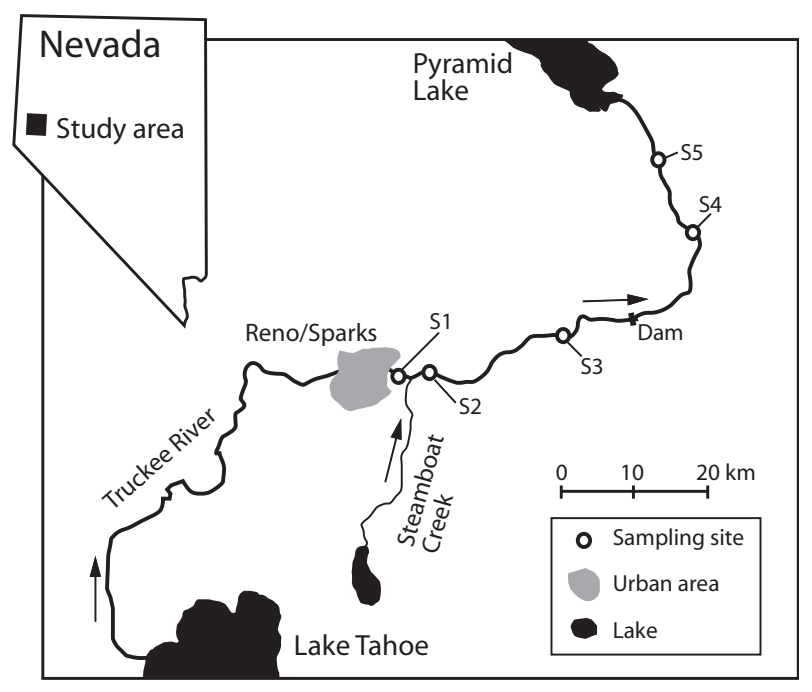

Figure 1. Location of the study sites along the Truckee River. The insert shows the study area within the state of Nevada.

an upgrade of the wastewater treatment facility that featured biological nutrient removal and denitrification.

We incubated artificial substrata at five stations between the city of Sparks and Pyramid Lake (Fig. 1), and assessed periphyton biomass and metabolism. The first station S1 (McCarran, city of Sparks at river km 97, 1335 $\mathrm{m}$ a.s.l.) was located about $4 \mathrm{~km}$ upstream of Steamboat Creek mouth near the East McCarran Boulevard Bridge. Stations S2 (Lockwood, river km 106), S3 (Clark, river $\mathrm{km} \mathrm{125),} \mathrm{S4} \mathrm{(S-S,} \mathrm{river} \mathrm{km} \mathrm{160),} \mathrm{and} \mathrm{S5} \mathrm{(Nixon,} \mathrm{river} \mathrm{km}$ 166) were located on a nutrient gradient of the impacted reach below the confluence with Steamboat Creek. The design of the study did not allow a rigorous statistical evaluation of nutrient effects on river periphyton because of the lack of replication (only one river).

\section{Physics and chemistry}

From August to mid October 1986, incident photosynthetically active radiation (PAR) was recorded at 10-min intervals at S1 using an LI-192 SA quantum sensor connected to a LI-1000 datalogger (LI-COR Inc., Lincoln, Nebraska). Incident PAR for the period mid-October to November 24 were calculated from hourly solar radiation data recorded in Sparks (Renewable Resource Data Center database http://rredc.nrel.gov/solar/). On a few occasions, underwater PAR intensities were measured with a LI-192 SA underwater quantum sensor connected to a LI-1000 datalogger (LI-COR Inc.), and vertical PAR attenuation coefficients $\left(\mathrm{k}_{\mathrm{PAR}}\right)$ were obtained by linear regression of $\ln [\operatorname{PAR}(\mathrm{z})]$ on depth $\mathrm{z}$. Water temperature was measured with thermistor probes (Yellow Springs Instrument Co., Yellow Springs, Ohio) at S1 several times a week between 6 August and 24 November 1986. 
Table 1. Temperature conditions and light $(\mathrm{PAR} \pm \mathrm{SD})$ in respiration chambers during metabolism measurements. avg $=$ average temperature of all measurements, $\min =$ average minimum temperature, $\max =$ average maximum temperature.

\begin{tabular}{lrrrrr}
\hline Period & \multicolumn{3}{c}{ Temperature $\left({ }^{\circ} \mathrm{C}\right)$} & \multicolumn{2}{c}{ PAR } \\
& avg & min & max & $\begin{array}{c}\text { Daily } \\
\text { integral } \\
\left(\mathrm{E} \mathrm{m}^{-2}\right)\end{array}$ & $\begin{array}{c}\text { Average } \\
\text { intensity } \\
\text { from } 10 \mathrm{am}- \\
2 \mathrm{pm} \\
\left(\mu \mathrm{E} \mathrm{m}^{-2} \mathrm{~s}^{-1}\right)\end{array}$ \\
\hline August & 23 & 18 & 27 & $35.0 \pm 2.8$ & $1161 \pm 69$ \\
November & 7 & 5 & 10 & $15.0 \pm 0.8$ & $644 \pm 23$ \\
\hline
\end{tabular}

Concentrations of soluble reactive phosphorus (SRP), ammonium $\left(\mathrm{NH}_{4}-\mathrm{N}\right)$, nitrite $\left(\mathrm{NO}_{2}-\mathrm{N}\right)$, and nitrate $\left(\mathrm{NO}_{3}\right.$ $\mathrm{N})$ were determined by the Desert Research Institute, Water Resources Center (Reno, Nevada) and Truckee River Monitoring Program of the cities of Reno and Sparks. All analyses were performed according to APHA (1976) and USEPA (1985).

\section{Periphyton}

Artificial substrata (unglazed quarry tiles: $1.5 \times 7.5 \times 15$ $\mathrm{cm}$ ) were incubated in riffle/run areas. Between 9 and 12 tiles were fastened in clusters on polypropylene netting (mesh size $=5 \mathrm{~mm}$ ). At each site, 4 to 5 clusters were secured to the river bottom with steel rods. Current velocities and water depth were measured on several occasions during incubation. Velocity measurements were taken above the tiles at 0.6 times depth and at $2-5 \mathrm{~cm}$ above the tile using an electromagnetic transducer (Marsh McBirney Inc., Frederick, MD).

Two sets of tiles were collected: A summer series was retrieved in August after 7 to $8.5 \mathrm{wk}$ of incubation in the river. An autumn series was collected in November after 9 to $11 \mathrm{wk}$ of incubation. The longer incubation during fall partly compensated for the lower temperature sum (Rushforth and Brock, 1991). After retrieval, the tiles were transported to $\mathrm{S} 1$ for metabolism measurements and periphyton sampling.

The outdoor setup for measuring periphyton metabolism (see Uehlinger and Brock, 1991) consisted of 13 continuous flow-through respiration chambers immersed in a water bath cooled with water from the river. The chambers were made of acrylic glass and operated simultaneously. Polypropylene inserts allowed varying the chamber volume from 1.2 to $1.9 \mathrm{~L}$. Internal circulation of water was provided by a submersible pump with variable discharge. A 16-channel peristaltic pump supplied corresponding river water (collected at each site simultaneously with tiles) to the chambers at rates varying between 0.35 and $0.90 \mathrm{~L} \mathrm{~h}^{-1}$. Containers with river water were stored in ice chests and cooled with river water. The

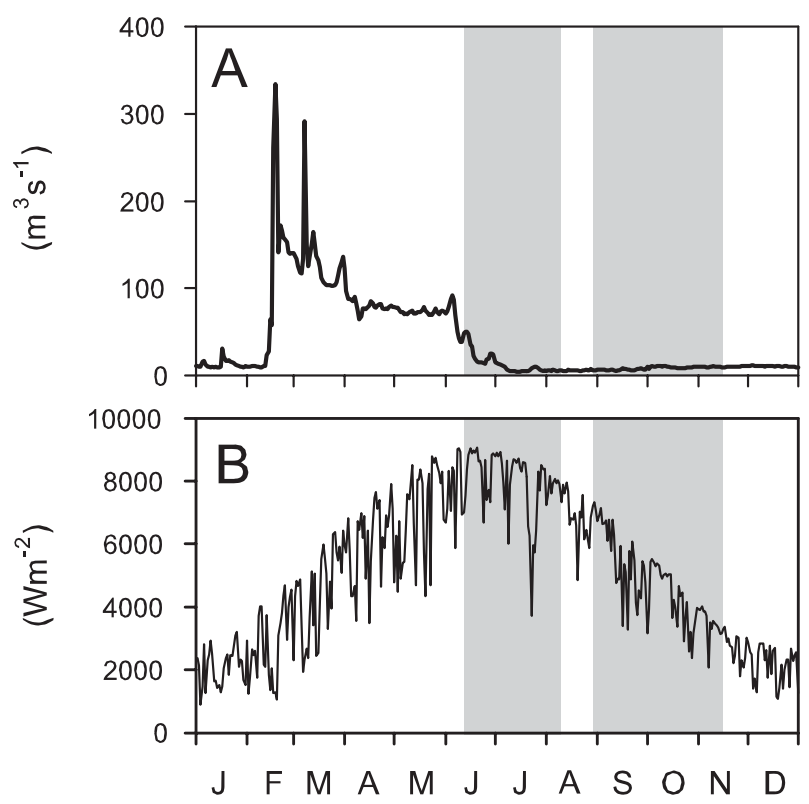

Figure 2. Discharge (A) and incident solar radiation (B) of the Truckee River at Sparks (USGS Station 10348200) in 1986. The shaded area delimits the periods when artificial substrata were incubated.

chamber outflow and water from the containers with river water were collected in $50 \mathrm{ml}$ BOD-bottles at intervals of 1 to $3 \mathrm{~h}$. Concentrations of dissolved oxygen were measured using a 5905 YSI self-stirring BOD bottle probe (Yellow Springs Instrument Co., Yellow Springs, Ohio). The intensity of incident light was reduced by $32 \%$ using black greenhouse shading to approximate in situ light intensities during incubation in the river. Temperature and light conditions in the respiration chambers during the metabolism measurements, which typically lasted for $24 \mathrm{~h}$, are summarized in Table 1. During measurements, average chamber temperatures exceeded the average river temperature (at S1) by $3{ }^{\circ} \mathrm{C}$ in August but were $1{ }^{\circ} \mathrm{C}$ below the average river temperature in November. Diel amplitudes were 2 (November) to $3^{\circ} \mathrm{C}$ (August) higher in the chambers than in the river. Net oxygen production $\beta(\mathrm{t})$ was calculated as:

$$
\beta(\mathrm{t})=\frac{\Delta \mathrm{O}_{2}}{\Delta \mathrm{t}}-\frac{\mathrm{f}}{\mathrm{V}}\left(\mathrm{O}_{2 \text { in }}-\mathrm{O}_{2}\right)
$$

where $\mathrm{O}_{2}$ is the oxygen concentration in each chamber $\left(\mathrm{mg} \mathrm{O}_{2} \mathrm{~L}^{-1}\right.$ ) as measured in the chamber outflow, $\frac{\Delta \mathrm{O}_{2}}{\Delta \mathrm{t}}$ is the change in oxygen concentration between two subsequent $\mathrm{O}_{2}$ measurements of the chamber outflow, $\mathrm{O}_{2 \text { in }}$ is the oxygen concentration $\left(\mathrm{mg} \mathrm{O}_{2} \mathrm{~L}^{-1}\right)$ in the containers with river water $\left(=\mathrm{O}_{2}\right.$ concentration in the chamber inflow), $\mathrm{f}$ is the rate of the chamber inflow $\left(\mathrm{L} \mathrm{h}^{-1}\right)$, and $\mathrm{V}$ is the water volume in the chamber $(\mathrm{L})$. Four metabolic parameters (Bott et al., 1985) were based on net production 
Summer

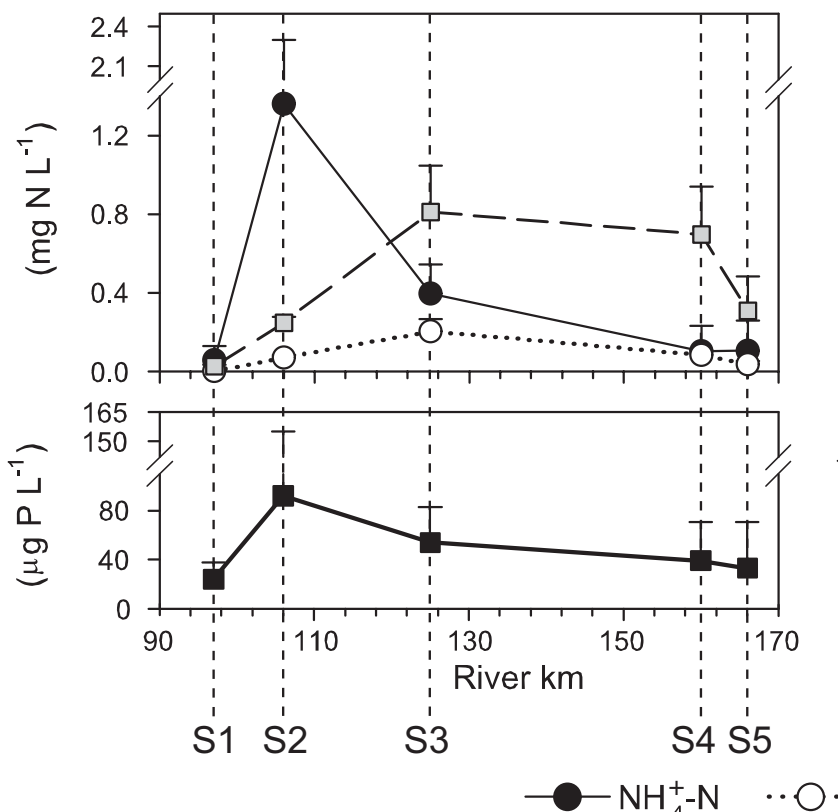

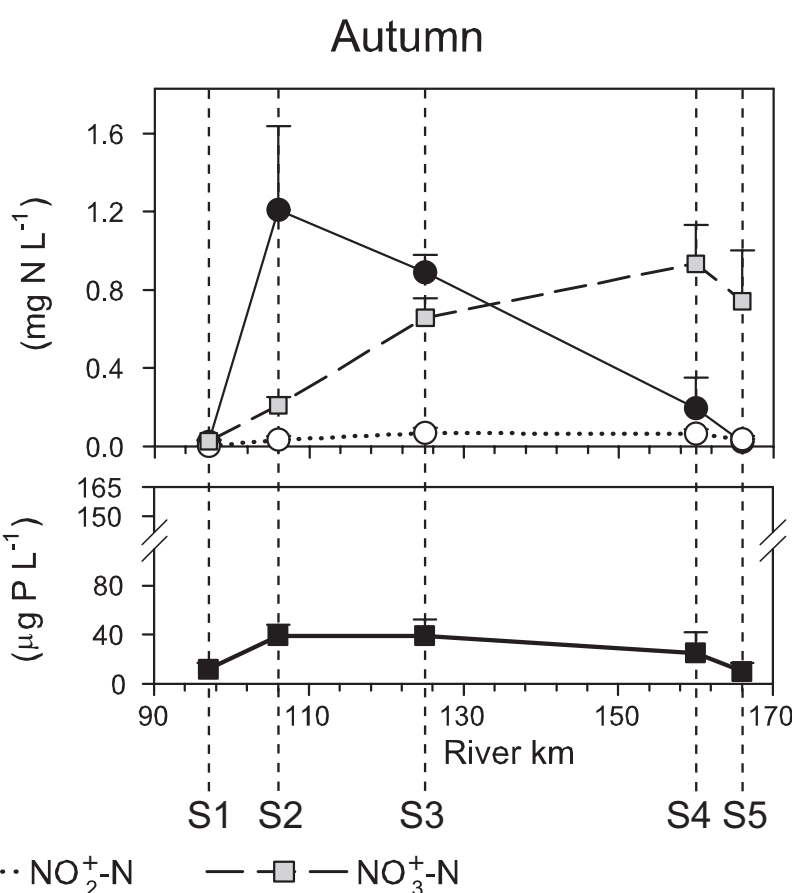

Figure 3. Concentration of ammonia $\left(\mathrm{NH}_{4}^{+}-\mathrm{N}\right)$, nitrite $\left(\mathrm{NO}_{2}^{+}-\mathrm{N}\right)$, nitrate $\left(\mathrm{NO}_{3}^{+}-\mathrm{N}\right)$ (upper panels), and soluble reactive phosphorus (lower panels), during summer (June - August) and autumn (September - November) 1986 in the lower Truckee River.

rates (equation 1): net daily metabolism (NDM), community respiration $(\mathrm{CR})$, gross primary production (GPP), and the ratio of gross primary production to community respiration $(\mathrm{P} / \mathrm{R})$. Net daily metabolism is the average net production rate of $\mathrm{O}_{2}$ during $24 \mathrm{~h}$. Average respiration during the dark period was extrapolated to $24 \mathrm{~h}$ to get estimates of CR. Gross primary production is sum of NDM and CR. Calculations of CR and GPP relied on the assumption that day respiration equals night respiration, but see Bott et al. (1985).

After metabolism measurements, samples of periphyton were removed from each tile by scrubbing a known area using templates and a stiff nylon brush. The resulting suspension was filtered through Whatman $\mathrm{GF} / \mathrm{F}$ glass fiber filters. Filters were stored at $-20^{\circ} \mathrm{C}$ prior to the analysis of chlorophyll $a$ and ash-free dry mass (AFDM). Filters were ground using a glass homogenizer with a Teflon pestle, and chlorophyll $a$ extracted with $90 \%$ acetone, and extracts cleared by centrifugation. After photometric determination of chlorophyll $a$ and pheopigments (APHA, 1985), the acidified extract and centrifuged sediment were combined and dried at $60^{\circ} \mathrm{C}$ to constant weight, ashed at $550^{\circ} \mathrm{C}$ for $2 \mathrm{~h}$, rewetted with distilled water, dried at $60^{\circ} \mathrm{C}$, and weighed. The rewetting and redrying steps of the procedure were included as a precaution for loss on combustion of water associated with clays (Greeson et al., 1977). The autotrophic index (AI) calculated as the ratio AFDM: chlorophyll $a$ is a measure to characterize the heterotrophic nature of the periphyton community (the inverse of AI describes the chlorophyll a content of periphytic biofilms). High AI values $(>100)$ have been associated with organic pollution (Weber, 1973).

\section{Data analysis}

Two-way ANOVA followed by post-hoc Tukey multiple comparison test was used to evaluate the effect of site and season (August, November) on biomass and metabolism. Data were transformed $\log (\mathrm{x}+1)$ to improve normality (Zar, 1984). Effects were considered significant at $\mathrm{p}<0.05$. Regressions and correlations were assumed significant at $\mathrm{p}<0.05$.

\section{Results}

\section{The physico-chemical environment}

The hydrograph of 1986 (USGS gage in Sparks) was characterized by 2 large floods (February and March), and relatively high flow until mid June (Fig. 2). Daily discharge was low in July $\left(5-7 \mathrm{~m}^{3} \mathrm{~s}^{-1}\right.$, apart from a minor flow peak of $10 \mathrm{~m}^{3} \mathrm{~s}^{-1}$ on July 26), August, and the first half of September. In the second half of September discharge began to increase, finally reaching $\sim 10 \mathrm{~m}^{3} \mathrm{~s}^{-1}$ in October and November. Water diversion for irrigation, especially at Derby Dam, reduced flow in the lower river to levels as low as $2 \mathrm{~m}^{3} \mathrm{~s}^{-1}$ (Rushforth and Brock, 1991). 
Table 2. Two-way ANOVA results for periphyton biomass and metabolism (log-transformed data except for net daily metabolism).

A) Chlorophyll- $a(\mathrm{chl} a)$, ash-free dry mass (AFDM) and the autotrophic index (AI).

\begin{tabular}{|c|c|c|c|c|c|c|c|}
\hline \multirow[t]{2}{*}{ Source } & \multirow[t]{2}{*}{$\mathrm{dF}$} & \multicolumn{2}{|c|}{$\operatorname{chl} \mathrm{a}$} & \multicolumn{2}{|c|}{ AFDM } & \multicolumn{2}{|c|}{ AI } \\
\hline & & SS & $\mathrm{p}$ & SS & $\mathrm{p}$ & SS & $\mathrm{p}$ \\
\hline Site & 4 & 17.7 & $<0.001$ & 9.3 & $<0.001$ & 1.2 & $<0.01$ \\
\hline Season & 1 & 42.0 & $<0.001$ & 9.8 & $<0.001$ & 13.8 & $<0.001$ \\
\hline Site $\mathrm{x}$ season & 4 & 14.2 & $<0.001$ & 5.4 & $<0.01$ & 4.1 & $<0.001$ \\
\hline
\end{tabular}

B) Net daily metabolism (NDM), gross primary production (GPP), community respiration (CR), and P/R ratio.

\begin{tabular}{|c|c|c|c|c|c|c|c|c|c|}
\hline \multirow[t]{2}{*}{ Source } & \multirow[t]{2}{*}{$\mathrm{dF}$} & \multicolumn{2}{|c|}{ NDM } & \multicolumn{2}{|c|}{ GPP } & \multicolumn{2}{|c|}{$\mathrm{CR}$} & \multicolumn{2}{|c|}{$\mathrm{P} / \mathrm{R}$} \\
\hline & & SS & $\mathrm{p}$ & SS & $\mathrm{p}$ & SS & $\mathrm{p}$ & SS & $\mathrm{p}$ \\
\hline Site & 4 & 9.7 & $<0.001$ & 5.9 & $<0.001$ & 30.2 & $<0.001$ & 2.8 & $<0.01$ \\
\hline Season & 1 & 19.2 & $<0.001$ & 4.8 & $<0.001$ & 18.1 & $<0.001$ & 0.9 & $<0.001$ \\
\hline Site $\mathrm{x}$ season & 4 & 47.6 & $<0.001$ & 1.9 & $<0.01$ & 5.8 & $<0.01$ & 0.4 & n.s. \\
\hline
\end{tabular}

Water depth ranged from 0.36 to $0.67 \mathrm{~m}$ in summer and from 0.27 to $0.63 \mathrm{~m}$ in autumn. Corresponding current velocities (measured at 0.6 times depth) varied between 0.50 and $0.97 \mathrm{~ms}^{-1}$ in summer and 0.48 and $0.99 \mathrm{~ms}^{-1}$ in winter. Average water temperatures during the two incubations were $20.2^{\circ} \mathrm{C}$ (summer) and $12.8^{\circ} \mathrm{C}$ (autumn). Solar radiation (Fig. 2) averaged $7886 \mathrm{Wm}^{-2}$ in summer and $4157 \mathrm{Wm}^{-2}$ in autumn. In July, vertical PAR attenuation coefficients ranged from 0.85 (S1) to $1.93 \mathrm{~m}^{-1}$ (S2).

During both incubation periods, concentrations of total dissolved inorganic nitrogen $\left(\mathrm{NO}_{3}-\mathrm{N}, \mathrm{NO}_{2}-\mathrm{N}, \mathrm{NH}_{4}-\right.$ $\mathrm{N})$ were relatively low at $\mathrm{S} 1\left(0.08 \pm 0.08 \mathrm{mg} \mathrm{N} \mathrm{L}^{-1}\right.$ in summer and $0.05 \pm 0.01 \mathrm{mg} \mathrm{N} \mathrm{L}^{-1}$ in autumn) and dominated by $\mathrm{NH}_{4}-\mathrm{N}$ (70\%) (Fig. 3). Ammonium peaked at $\mathrm{S} 2$ in summer $\left(1.36 \pm 0.94 \mathrm{mg} \mathrm{N} \mathrm{L}^{-1}\right)$ and autumn (1.21 $\pm 0.43 \mathrm{mg} \mathrm{N} \mathrm{L}{ }^{-1}$, Fig. 3). During summer, $\mathrm{NH}_{4}-\mathrm{N}$ rapidly declined along the $60 \mathrm{~km}$ reach from $\mathrm{S} 2$ to $\mathrm{S} 5$, and $\mathrm{NO}_{2}-\mathrm{N}$ and $\mathrm{NO}_{3}-\mathrm{N}$ reached maximum concentrations at $\mathrm{S} 3\left(0.20 \pm 0.06 \mathrm{NO}_{2}-\mathrm{N} \mathrm{L}^{-1}, 0.80 \pm 0.24 \mathrm{NO}_{3}-\mathrm{N} \mathrm{L}^{-1}\right)$. In autumn, the longitudinal trend of decreasing $\mathrm{NH}_{4}-\mathrm{N}$ was less pronounced and the $\mathrm{NO}_{3}-\mathrm{N}$ maximum was shifted downstream (presumably reflecting reduced nitrification rates at relatively low water temperatures). Concentrations of soluble reactive phosphorus (SRP) averaged $24 \pm 14$ (summer) and $12 \pm 5 \mu \mathrm{g} \mathrm{P} \mathrm{L}{ }^{-1}$ (autumn) at S1, peaked at S2 with $92 \pm 63 \mu \mathrm{g} \mathrm{P} \mathrm{L}{ }^{-1}$ (summer) and $39 \pm$ $9 \mu \mathrm{g} \mathrm{P} \mathrm{L}{ }^{-1}$ (autumn), and declined downstream (Fig. 3). SRP concentrations tended to be lower in autumn than in summer.

\section{Periphyton}

Analysis of variance suggested site and season as significant sources of variation in chlorophyll $a$, ash-free dry mass, autotrophic index (AI), and the four metabolism parameters (Table 3 ). The interaction of site $\mathrm{x}$ season was
Table 3. Correlations between concentrations of soluble reactive phosphorus (SRP) and total dissolved inorganic nitrogen (TDN) against periphyton biomass and metabolism parameters. AFDM = ash-free dry mass, $\mathrm{AI}=$ autotrophic index, $\mathrm{GPP}=$ gross primary production, $\mathrm{CR}=$ community respiration. $\mathrm{n} . \mathrm{s}$. $=$ non significant.

\begin{tabular}{lrrrlll}
\hline & \multicolumn{2}{c}{ August } & & \multicolumn{2}{c}{ November } \\
& SRP & TDN & & SRP & TDN \\
\cline { 1 - 2 } \cline { 5 - 6 } Chlorophyll $a$ & 0.78 & 0.81 & & 0.48 & 0.45 \\
AFDM & 0.66 & 0.72 & & n.s. & n.s. \\
AI & -0.73 & -0.57 & & n.s. & n.s. \\
GPP & 0.65 & 0.55 & & n.s. & n.s. \\
CR & 0.83 & 0.77 & & n.s. & n.s. \\
P/R & -0.63 & -0.64 & & n.s. & n.s \\
\hline
\end{tabular}

significant for both biomass parameters, AI, and three metabolism parameters (net daily metabolism, gross primary production, and community respiration). The correlation between nutrient concentration and periphyton biomass or metabolism indicates the effects of nutrient enrichment were mostly evident in August and not in November (Table 5). However, the limitation of the research to one river system precludes a rigorous statistical evaluation of nutrient effects on periphyton generally.

Biomass: Variation in chlorophyll $a$ and ash-free dry mass (AFDM) along the study reach was distinct and significant at the end of both incubation periods (Fig. 4, Table 2). In August, AFDM and chlorophyll $a$ were relatively low at $\mathrm{S} 1\left(53 \pm 26 \mathrm{mg}\right.$ chl $a \mathrm{~m}^{-2}, 18 \pm 11 \mathrm{~g} \mathrm{AFDM}$ $\left.\mathrm{m}^{-2}\right)$, peaked at $\mathrm{S} 2\left(290 \pm 116 \mathrm{mg}\right.$ chl $a \mathrm{~m}^{-2}, 49 \pm 13 \mathrm{~g}$ AFDM $\mathrm{m}^{-2}$ ), and declined further downstream (Fig. 4). Differences in biomass between the stations S1, S4, and S5 were not significant (Tukey's test, $\mathrm{p}>0.05$ ). We observed a similar longitudinal pattern in November, except that there was a significant increase in chlorophyll $a$ and AFDM between S4 and S5 for reasons that are not clear (Fig. 4). Chlorophyll $a$ and AFDM were higher on tiles in 


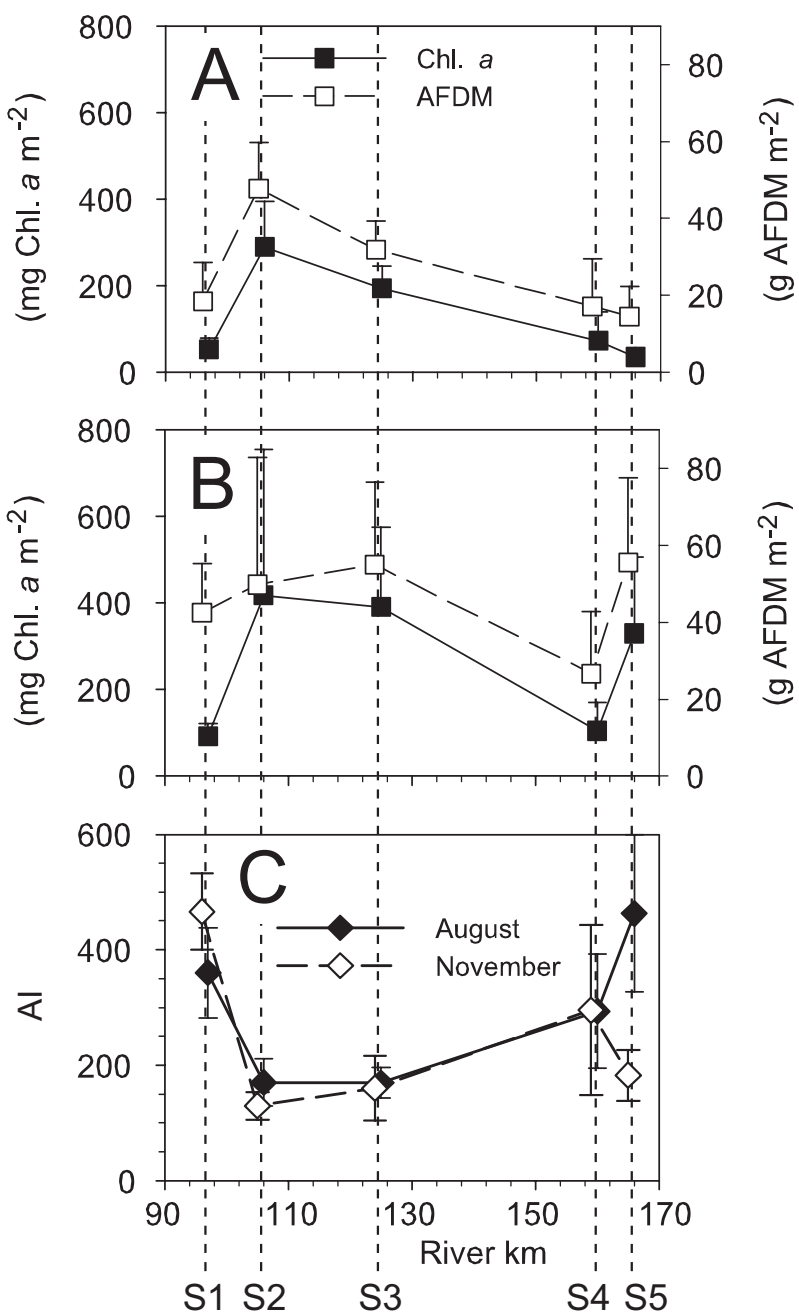

Figure 4. Chlorophyll $a$ and ash-free dry mass (AFDM) grown on tiles (A) in August and (B) in November, and the autotrophic index (AI) in August and November (C).

November than August, a similar pattern to that observed on natural substrata (J. Brock, Unpublished Data). The autotrophic index decreased from $360 \pm 78$ (August) and $466 \pm 66$ (November) at $S 1$ to $170 \pm 41$ (August) and 129 \pm 24 (November) at $\mathrm{S} 2$, and increased from S3 to the end of the reach, particularly in August (Fig. 4).

Metabolism: A significant increase in gross primary production (GPP) and community respiration (CR) downstream of Steamboat Creek characterized the spatial (longitudinal) pattern in periphyton metabolism in August and November (Fig. 5A; B, Table 2). In August, gross primary production increased from $3.3 \pm 0.8 \mathrm{~g} \mathrm{O}_{2}$ $\mathrm{m}^{-2} \mathrm{~d}^{-1}$ at $\mathrm{S} 1$ to $9.1 \mathrm{~g} \pm 1.4 \mathrm{~g} \mathrm{O}_{2} \mathrm{~m}^{-2} \mathrm{~d}^{-1}$ at $\mathrm{S} 2$, stayed at a high level $\left(>7.8 \mathrm{~g} \mathrm{O}_{2} \mathrm{~m}^{-2} \mathrm{~d}^{-1}\right)$ at S3 and $\mathrm{S} 4$, and finally declined to $4.8 \pm 2.3 \mathrm{~g} \mathrm{O}_{2} \mathrm{~m}^{-2} \mathrm{~d}^{-1}$ at $\mathrm{S} 5$. Corresponding values of CR were $2.1 \pm 0.4$ and $10.1 \pm 1.3 \mathrm{~g} \mathrm{O}_{2} \mathrm{~m}^{-2} \mathrm{~d}^{-1}$ at $\mathrm{S} 1$ and $\mathrm{S} 2$, respectively, and $3.0 \pm 2.0 \mathrm{~g} \mathrm{O}_{2} \mathrm{~m}^{-2} \mathrm{~d}^{-1}$ at $\mathrm{S} 5$. Differences between sites were less pronounced in
November when GPP ranged from $2.2 \pm 0.6$ (S4) to 4.6 $\pm 1.0(\mathrm{~S} 3)$, and CR from $0.6 \pm 0.2$ (S4) to $1.7 \pm 0.9$ (S3). Net daily metabolism (NDM) in August was $1.2 \pm 0.8 \mathrm{~g}$ $\mathrm{O}_{2} \mathrm{~m}^{-2} \mathrm{~d}^{-1}$ at $\mathrm{S} 1$, decreasing to $-1.0 \pm 0.9 \mathrm{~g} \mathrm{O}_{2} \mathrm{~m}^{-2} \mathrm{~d}^{-1}$ at $\mathrm{S} 2$, and peaked at $2.6 \pm 0.9 \mathrm{~g} \mathrm{O}_{2} \mathrm{~m}^{-2} \mathrm{~d}^{-1}$ at $\mathrm{S} 5$ (Fig. 5C). In November, NDM ranged from $1.3 \pm 0.9$ to $2.1 \pm 0.6 \mathrm{~g} \mathrm{O}_{2}$ $\mathrm{m}^{-2} \mathrm{~d}^{-1}$. The $\mathrm{P} / \mathrm{R}$ ratios varied between $0.9 \pm 0.1(\mathrm{~S} 2)$ and $1.8 \pm 0.4$ (S5) in August, and between $2.0 \pm 0.6$ (S3) and $3.3 \pm 2.3$ (S5) in November (Fig. 5D). Both NDM and $\mathrm{P} / \mathrm{R}$ were significantly higher in November than in August (Table 3), but post-hoc Tukey multiple comparisons indicated no significant differences between sites in November. Chlorophyll $a$ and AFDM explained 43 to $67 \%$ of the variation in GPP, and 56 to $81 \%$ in CR in August, but only 26 to $35 \%$ of the variation in GPP and CR could be attributed to variation in chlorophyll a and ash-free dry mass (linear regression analysis) in November.

\section{Discussion}

Our study showed that in the Truckee River the response of periphyton metabolism to nutrient enrichment is strongly influenced by seasonal changes in light and temperature. During both incubation periods, flow was constant and low, longitudinal patterns in dissolved inorganic nitrogen (TDN) and soluble reactive phosphorus (SRP) were similar, while light and temperature conditions distinctly differed. The lack of hydrological disturbance during extended time periods is expected to favor biotic processes such as grazing, or the aging and subsequent sloughing of biofilms (e.g., Biggs, 1996; Fisher and Grimm, 1991). Poor water quality (e.g., high ammonia concentrations) downstream of Steamboat Creek inlet may have affected benthic grazers and, as a consequence, enhanced periphyton accrual (in addition to the stimulation of periphyton growth by the increased nutrient supply). However, the biomass of invertebrates classified as grazers correlated neither with periphyton biomass nor with ammonia and nitrite (Rushforth and Brock, 1991). Despite relatively long incubation periods, we found no evidence for autogenic sloughing.

Periphyton biomass and metabolism paralleled SRP and TDN concentrations in August. The high explanatory power of correlations between periphyton and nutrients suggests either SRP or TDN as a major stimulant of biomass and metabolism during summer. Upstream of the Steamboat Creek inlet, SRP varied between 12 and $24 \mu \mathrm{g} \mathrm{P} \mathrm{L}{ }^{-1}$, and TDN between 0.05 and $0.08 \mathrm{mg} \mathrm{N}$ $\mathrm{L}^{-1}$. The corresponding molar $\mathrm{N}$ : $\mathrm{P}$ ratios (TDN: SRP) ranged from 7.5 (summer) to 9.1 (autumn). The transition range from nutrient saturation to nutrient limitation is 0.6 to $10 \mu \mathrm{g} \mathrm{P} \mathrm{L}^{-1}$ for inorganic $\mathrm{P}$ and 0.05 to 0.06 mg N L ${ }^{-1}$ for inorganic N (e.g., Bothwell, 1989; Grimm and Fisher, 1986; Newbold, 1992). Relatively high SRP 

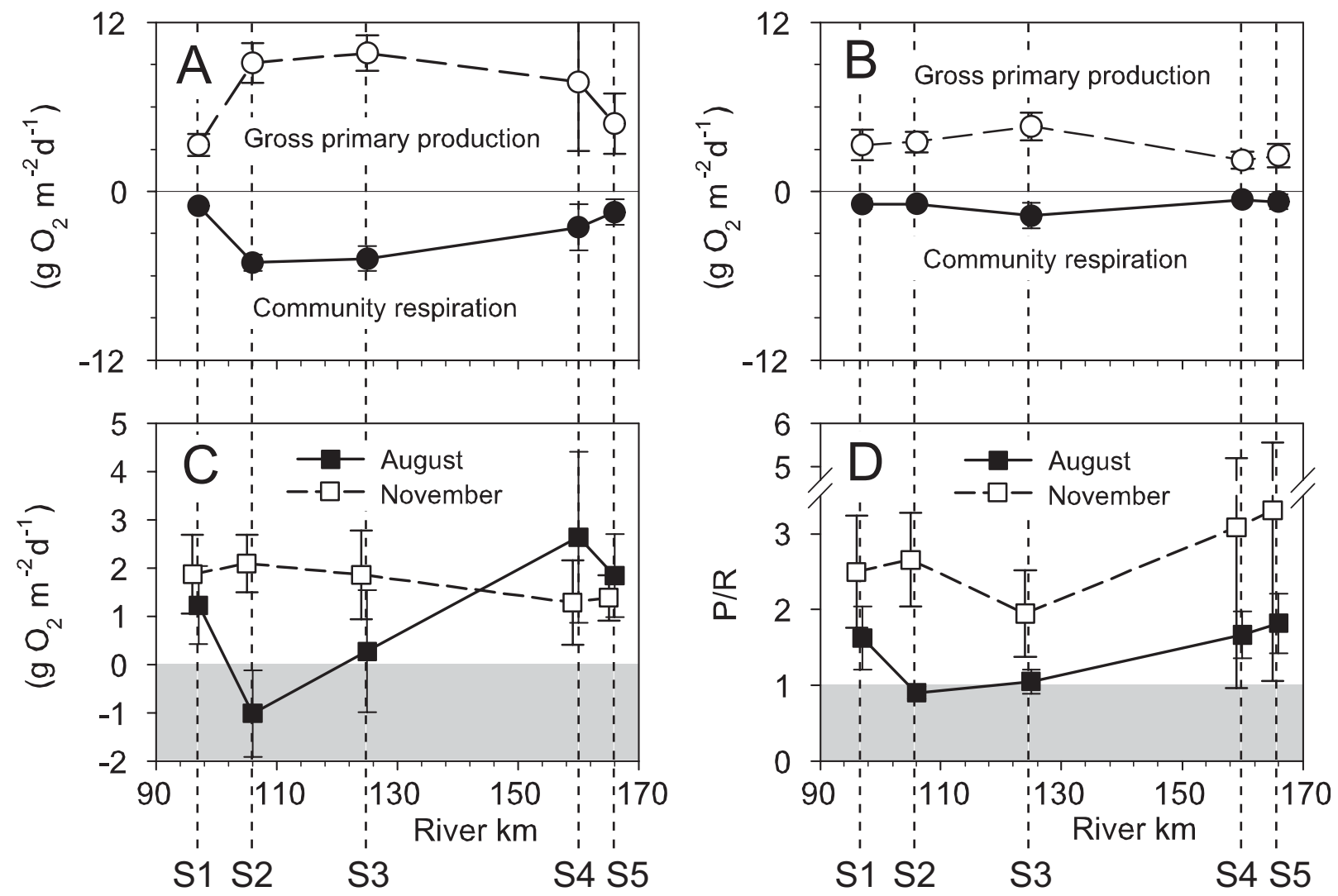

Figure 5. Periphyton gross primary production and community respiration (A) in August and (B) November. Net daily metabolism (C), and $\mathrm{P} / \mathrm{R}$ ratio (D) of the periphyton community in August and November. The shaded areas delimit negative net daily metabolism rates and P/R values $\leq 1$.

concentrations and low $\mathrm{N}: \mathrm{P}$ ratio suggest $\mathrm{N}$ limitation of periphyton upstream of the Steamboat Creek inlet. Steamboat Creek, carrying the treated wastewater of a large sewage treatment facility, increased TDN and SRP in the Truckee River far above limiting concentrations. After a flow distance of $65 \mathrm{~km} \mathrm{SRP} \mathrm{and,} \mathrm{especially,} \mathrm{TDN}$ were still elevated. Stimulation of periphyton accrual may not only result from increased concentrations of $\mathrm{P}$ and N. For example, flume experiments by Wuhrmann and Eichenberger (1975) showed that minor additions of sewage remarkably enhanced periphyton growth. Wuhrmann and Eichenberger (1975) hypothesized that minor nutrients occurring in wastewater may account for the growth stimulating effect.

The increase in periphyton biomass (chlorophyll $a$ and ash-free dry mass) downstream of Steamboat Creek inlet was quite substantial in August. In terms of chlorophyll $a$, the river shifted from mesotrophy to eutrophy. The level considered to cause nuisance conditions (200 mg chl $a \mathrm{~m}^{-2}$ (Dodds et al., 1998; Welch et al., 1988) was approached (193 mg chl $a \mathrm{~m}^{-2}$ at S2) or exceeded (290 $\mathrm{mg}$ chl $a \mathrm{~m}^{-2}$ at S3). The increase in biomass was paralleled by a decline in the autotrophic index (AI). This change in AI primarily reflects a reduction of nutrient stress downstream of Steamboat Creek inlet and not a reduction of organic pollution, which is expected to be highest at S2. The chlorophyll content of algae has been shown to decline with increasing $\mathrm{N}$ or $\mathrm{P}$ limitation (Healy and Hendzel, 1975; Rhee, 1978; Uehlinger, 1981).

In November, both chlorophyll $a$ and ash-free dry mass were about $2 \times$ higher than in August, and the link between nutrients and periphyton biomass was not evident (only chlorophyll $a$ correlated with $\mathrm{N}$ and P). The increasing trend in periphyton biomass on tiles during the onset of colder autumn temperatures paralleled that observed on cobble substrata sampled from the Truckee River during the same period. Although the species composition tended to be less rich on tiles compared to natural substrata, the range of periphyton biomass overlapped with respect to chlorophyll $a$ determined on tiles and cobbles, and both followed similar trends spatially (J. T. Brock, Unpublished Data). Seasonal shifts in composition of the diatom community were observed between summer and fall, with Nitzschia dissipata dominating the fall community in the nutrient-enriched zone downstream from Steamboat Creek (S2-S3) during autumn (Rushforth and Brock, 1991). High periphyton biomass during periods of apparently less favorable light and tem- 
perature conditions has been observed elsewhere (Delong and Brusven, 1992; Shamsudin and Sleigh, 1994; Uehlinger et al., 1996). Seasonally changing responses of periphyton biomass to nutrient amendments was found in 12 New Zealand gravel bed streams, where stimulation of periphyton accrual was maximum in summer, minimum in winter, and intermediate in autumn and spring (Francoeur et al., 1999). The pattern found in this study of elevated periphyton biomass during the cold season was observed in the Truckee River in several other subsequent years for which chlorophyll and AFDM data are available (J. T. Brock, Unpublished Data). These elevated biomass conditions observed for periphyton during late autumn and early winter may be associated with seasonally-reduced grazing pressure from benthic macroinvertebrates due to reduced numbers or lowered metabolic activity associated with cold temperatures.

The change in periphyton metabolism downstream of the point source was considerable, at least under the favorable light and temperature conditions in August. Daily gross primary production increased from 3.3 to $9.1 \mathrm{~g} \mathrm{O}_{2}$ $\mathrm{m}^{-2} \mathrm{~d}^{-1}$. However, these maximum rates are not exceptionally high compared with open-canopied rivers subject to similar or even minor nutrient supply and with periphyton as the dominant primary producer (e.g., Brock et al., 1999; Busch and Fisher, 1981; Cushing and Wolf, 1984; Fisher et al., 1982; Minshall, 1978; Uehlinger and Naegeli, 1998). In August, community respiration (CR) of periphyton responded to the enhanced nutrient supply with a significant increase (from 2.8 to $10.1 \mathrm{~g} \mathrm{O}_{2} \mathrm{~m}^{-2} \mathrm{~d}^{-1}$ ), and about $82 \%$ of the variation in CR could be explained by the variation in GPP (linear regression), indicating a close link between respiration and primary production. Periphyton respiration includes algal respiration, which is often assumed to be $10-50 \%$ of gross primary production (McAllister et al., 1964; Whittaker and Likens, 1975) and respiration of heterotrophic organisms located at the surface or in the biofilm matrix. In contrast to primary production, measurements of periphyton respiration provide limited information with respect to respiration at the ecosystem level since hyporheic respiration of open-canopied streams is known to contribute between 40-90\% to ecosystem respiration (Grimm and Fisher, 1984; Naegeli and Uehlinger, 1997).

In November, gross primary production and respiration were significantly lower than in August (in contrast to biomass), presumably due to reduced light intensity and temperature. This finding concurs with the general annual patterns of primary production and respiration rates typically observed in many streams (e.g., Cushing and Wolf, 1984; Servais et al., 1984; Uehlinger, 1993). Periphyton metabolism in the Truckee River lacked an apparent response to the enhanced nutrient availability downstream of the point source in November. In contrast, Guasch (1995) found a distinct increase in net daily me- tabolism and gross primary production following nutrient addition $(\mathrm{P}, \mathrm{N}, \mathrm{K})$ to stream flumes in winter, despite low light intensity $\left(31 \mathrm{E} \mathrm{m}^{-2} \mathrm{~d}^{-1}\right)$ and temperature $\left(3.6^{\circ} \mathrm{C}\right)$.

The $\mathrm{P} / \mathrm{R}$ ratio characterizes the balance between auto- and heterotrophic processes in the periphyton community. If algae respire between 10 and $50 \%$ of gross primary production, upper limits of $\mathrm{P} / \mathrm{R}$ of periphyton are expected to range from 2-10 (respiration of heterotrophic microorganisms occurring in autotrophic biofilms not included). The $\mathrm{P} / \mathrm{R}$ of periphyton (ratio based on daily gross primary production and respiration rates) has been reported to be $>1$ (Munn and Brusven, 2004; Peterson et al., 1986). The transient depression of $\mathrm{P} / \mathrm{R}$ downstream of Steamboat Creek inlet in August to values $<1$ can be the outcome of several mechanisms, including a shift in the relative proportion of the photic and aphotic zone with increasing biofilm density (major parts of dense biofilms can be light limited) (Dodds et al., 1999), the supply of organic matter from the sewage treatment plant supporting additional heterotrophic activity (besides algal respiration), and the oxygen consumption by nitrifying bacteria. Concentrations of $\mathrm{NH}_{4}-\mathrm{N}$ and $\mathrm{NO}_{2}-\mathrm{N}$ indicated that the reach between river $\mathrm{km} 101$ and 125 is an active zone of nitrification. We are aware that problems may arise if $P / R$ is used to characterize the trophic status of functional compartments exhibiting substantial chemoautotrophic activity. Metabolism of the periphyton community became more autotrophic with the seasonal change; in November P/R ratios averaged 2.6 compared to 1.4 in August. The reduction of light and temperature by 60 and 70\%, respectively, from August to November apparently influenced gross primary production and community respiration to a different extent. Primary production is known to be less temperature dependent than respiration (Busch and Fisher, 1981; Phinney and McIntire, 1965). For example, Busch and Fisher (1981) reported $\mathrm{Q}_{10}$ temperature coefficients of 1.5 for gross primary production and 2.5 for community respiration in Sycamore Creek. Photosynthesis of epilithic algae has been reported to be light saturated at intensities ranging from 100 to $600 \mu \mathrm{E} \mathrm{m}^{-2} \mathrm{~s}^{-1}$ (e.g., Boston and Hill, 1991; Dodds et al., 1999; Hill, 1996; Hill and Boston, 1991). Compared to these values, PAR intensities in November were still relatively high $\left(>600 \mu \mathrm{E} \mathrm{m}^{-2} \mathrm{~s}^{-1}\right.$ for about $4 \mathrm{~h}$ each day, Table 1), and may account for the relatively moderate reduction in GPP.

To summarize, periphyton responded to nutrient enrichment from a point source with a significant increase in biomass and metabolism, but only under favorable light and temperature conditions prevailing during summer in a desert river. The effect of nutrient enrichment was hardly evident in autumn, indicating a strong seasonality in the response to nutrient amendment. The balance between auto- and heterotrophic processes in the periphyton community also showed distinct seasonal 
variation under conditions of constant and low flow. The conditions observed of negative net daily oxygen metabolism during summer have implications to the oxygen balance in this and other desert rivers, where low dissolved oxygen conditions may prevail seasonally and serve as a stressor for aquatic biota.

\section{Acknowledgments}

We appreciate the numerous contributions of H. Runke (Barr Engieering Co.), who provided the stimulus and guidance for this study. We thank T. Morrison and R. Vonarb for assistance with field collections. J. Cooper (Nevada Department of Environmental Protection), T. Swan (Truckee Meadows Water Reclamation Facility), L. Crowe (Washoe County Department of Water Resources) and J. Heidker (Desert Research Institute) provided assistance with facilities and laboratory analyses. The research was conducted at the Main Station Farm through the cooperation of the Department of Agriculture of University of Nevada, Reno. Equipment and facilities was provided by the Department of Biological Sciences at Idaho State Univesity. This research was funded in part by contract No. 68-03-6242 to Earth Metrics Inc., Burlingame, CA, from the U.S. Environmental Protection Agency. We appreciate the helpful comments of three anonymous reviewers. We are especially grateful to W. Minshall for his suggestions and encouragement throughout our research on the Truckee River.

\section{References}

APHA, 1976. Standard methods for the examination of water and waste water. American Public Health Association, Washington, D.C.

Biggs, B. J. F., 1995. The contribution of flood disturbance, catchment geology and land use to the habitat template of periphyton in stream ecosystems. Freshw. Biol. 33: 419-438.

Biggs, J. F. B., 1996. Patterns in benthic algae of streams. In: R. J. Stevenson, M. L. Bothwell, and R. L. Lowe (eds.), Algal ecology. Freshwater benthic ecosystems. Academic Press, San Diego. pp. 31-56.

Biggs, B. J. F., 2000. Eutrophication of streams and rivers: dissolved nutrient-chlorophyll relationships for benthic algae. J. N. Am. Benthol. Soc. 19: 17-31.

Borchardt, M. A., 1996. Nutrients. In: R. J. Stevenson, M. L. Bothwell, and R. L. Lowe (eds.), Algal ecology. Freshwater benthic ecosystems. Academic Press, San Diego. pp. 183-227.

Boston, H. L. and W. R. Hill, 1991. Photosynthesis-light relations of stream periphyton. Limnol. Oceanogr. 36: 644-656.

Bothwell, M. L., 1989. Phosphorus-limited growth dynamics of lotic periphytic diatom communities: areal biomass and cellular growth rate responses. Can. J. Fish. Aquat. Sci. 46: 1293-1301.

Bott, T. L., J. T. Brock, C. S. Dunn, R. J. Naiman, R. W. Ovink and R. C. Petersen, 1985. Benthic community metabolism in 4 temperate stream systems: An inter-biome comparison and evaluation of the river continuum concept. Hydrobiol. 123: 3-46.
Brock, J. T., T. V. Royer, E. B. Snyder and S. A. Thomas, 1999. Periphyton metabolism: a chamber approach. In: R. H. Webb, J. C. Schmidt, G. R. Marzolf and R. A. Valdez (eds.), The controlled flood in Grand Canyon. Geophysical Monograph 110; American Geophysical Union. pp. 217-224.

Busch, D. E. and S. G. Fisher, 1981. Metabolism of a desert stream. Freshw. Biol. 11: 301-308.

Bushong, S. J. and R. W. Bachmann, 1989. In situ nutrient enrichment experiments with periphyton in agriculturals streams. Hydrobiol. 178: 1-10.

Chessman, B. C., P. E. Hutton and J. M. Burch, 1992. Limiting nutrients for periphyton growth in sub-alpine, forest, agricultural and urban streams. Freshw. Biol. 28: 349-361.

Cushing, C. E. and E. G. Wolf, 1984. Primary production in rattlesnake springs (Washington, USA) a cold desert spring-stream. Hydrobiol. 114: 229-236.

Delong, M. D. and M. A. Brusven, 1992. Patterns of periphyton chlorophyll $a$ in an agricultural nonpoint source impacted stream. Water Res. Bul. 28: 731-741.

Dodds, W. K., B. J. F. Biggs and R. L. Lowe, 1999. Photosynthesis-irradiance patterns in benthic microalgae: variations as a function of assemblage thickness and community structure. J. Phycol. 35: 42-53.

Dodds, W. K., J. R. Jones and E. B. Welch, 1998. Suggested classification of stream trophic state: distribution of temperate stream types by chlorophyll, total nitrogen, and phosphorus. Water Res. 32: 1455-1462.

Dodds, W. K., V. H. Smith and K. Lohmann, 2002. Nitrogen and phosphorus relationships to benthic algal biomass in temperate streams. Can. J. Fish. Aquat. Sci. 59: 865-874.

Fisher, S. G. and N. B. Grimm, 1988. Disturbance as a determinant of structure in a Sonoran Desert stream ecosystem. Verh. Int. Ver. Limnol. 23: 1183-1189.

Fisher, S. G. and N. B. Grimm, 1991. Stream and disturbance: are cross-ecosystem comparison useful. In: J. Cole, G. Lovett and S. Findlay (eds.), Comparative analysis of ecosystems. Patterns, mechanisms, and theories. Springer, New York. pp. 196-221.

Fisher, S. G., L. J. Gray, N. B. Grimm and D. E. Busch, 1982. Temporal succession in a desert stream ecosystem following flash flooding. Ecological Monographs 52: 93-110.

Francoeur, S. N., B. J. F. Biggs, R. A. Smith and R. L. Lowe, 1999. Nutrient limitation of algal biomass accrual in stream: seasonal patterns and a comparison of methods. J. N. Am. Benthol. Soc. 18: 242-260.

Greeson, P. E., T. A. Ehrlke, G. A. Irwin, B. W. Lium and K. V. Slack, 1977. Methods for Collection and Analysis of Aquatic Biological and Microbiological Samples. Chapter A4 in Techniques of Water-Resources Investigations of the United States Geological Survey. Book 5, Laboratory Analysis. Washington, DC.

Grimm, N. B. and S. G. Fisher, 1984. Exchange between interstitial and surface water: Implication for stream metabolism and nutrient cycling. Hydrobiol. 111: 219-228.

Grimm, N. B. and S. G. Fisher, 1986. Nitrogen limitation in a Sonoran Desert (Arizona, USA) stream. J. N. Am. Benthol. Soc. 5: $2-15$.

Grimm, N. B. and S. G. Fisher, 1989. Stability of periphyton and macroinvertebrates to disturbance by flash floods in a desert stream. J. N. Am. Benthol. Soc. 8: 293-297.

Guasch, H., E. Marti and S. Sabater, 1995. Nutrient enrichment effects on biofilm metabolism in a Mediterranean stream. Freshw. Biol. 33: 373-383.

Healy, F. P. and L. L. Hendzel, 1975. Effect of phosphorus deficiency on two algae growing in chemostats. J. Phycol. 11: 303-309.

Hill, A. R., 1996. Effects of light. In: R.J. Stevenson, M.L. Bothwell, and R.L. Lowe (eds.), Algal ecology. Freshwater benthic ecosystems. Academic Press, San Diego. pp. 121-148.

Hill, W. R. and H. L. Boston, 1991. Community development alters photosynthesis-irradiance relations in stream periphyton. Limnol. Oceanogr. 36: 1375-1389. 
McAllister, C. D., N. Shah and J. D. H. Strickland, 1964. Marine phytoplankton photosynthesis as a function of light intensity. Can. J. Fish. Res. Board 21: 159-181.

Minshall, W. G., 1978. Autotrophy in stream ecosystems. BioScience 28: 767-771.

Munn, M. D. and M. A. Brusven, 2004. The influence of Dworshak Dam on eplilithic community metabolism in the Clearwater River, U.S.A. Hydrobiol. 513: 121-127.

Naegeli, M. W. and U. Uehlinger, 1997. Contribution of the hyporheic zone to ecosystem metabolism in a prealpine gravel-bed river. J. N. Am. Benthol. Soc. 16: 794-804.

Newbold, D. J., 1992. Cycles and spirals of nutrients. In: P. Calow and G. E. Petts (eds.), The rivers handbook. Hydrological and ecological principles. Blackwell, London. pp. 379-408.

Peterson, B. J., J. E. Hobbie and T. L. Corliss, 1986. Carbon flow in a tundra stream ecosystem. Can. J. Fish. Aquat. Sci. 43: $1259-1270$.

Phinney, H. K. and C. D. McIntire, 1965. Effect of temperature on metabolism of periphyton communities developed in laboratory streams. Limnol. Oceanogr. 10: 341-344.

Pringle, C. M., 1987. Effects of water and substratum nutrient supplies on lotic periphyton growth: An integrated Bioassay. Can. J. Fish. Aquat. Sci. 44: 619-629.

Pringle, C. M. and J. A. Bowers, 1983. An in situ substratum fertilization technique: Diatom colonization on nutrient-enriched, sand substrata. Can. J. Fish. Aquat. Sci. 41: 1247-1251.

Rhee, G.-Y., 1978. Effect of N:P atomic ratios and nitrate limitation on algal growth, cell composition, and nitrate uptake. Limnol. Oceanogr. 23: 10-25.

Rushforth, S. R. and J. T. Brock, 1991. Attached diatom communities from the lower Truckee River, summer and fall 1986. Hydrobiol. 224: 49-64.

Servais, P., E. Debecker and G. Billen, 1984. Annual cycle of gross primary production and respiration in the Viroin River (Belgium). Hydrobiol. 111: 57-64.

Shamsudin, L. and M. A. Sleigh, 1994. Seasonal changes in composition and biomass of epilitihc algal floras of a chalk stream and a soft water stream with estimates of production. Hydrobiol. 273: $131-146$
Taylor, S. L., S. C. Roberts, C. J. Walsh and B. E. Hatt, 2004. Catchment urbanization and increased algal biomass in streams: linking mechanisms to management. Freshw. Biol. 49: 835-851.

Uehlinger, U., 1981. Experimental studies on the autecology of Aphanizomenon flos aquae. Arch. Hydrobiol. Suppl. 60: 260-288.

Uehlinger, U., 1993. Primary production and respiration in the outlet of an eutrophic lake (River Glatt, Switzerland). Arch. Hydrobiol. 128: 39-55.

Uehlinger, U. and J. T. Brock, 1991. The assessment of river periphyton metabolism: a method and some problems. In: Whitton, B.A., E. Rott and G. Friedrich (eds.), Use of algae for monitoring rivers. Institute für Botanik. Universität Innsbruck, Innsbruck, Austria. pp. 175-181.

Uehlinger, U., H. Bührer and P. Reichert, 1996. Periphyton dynamics in a floodprone prealpine river: Evaluation of significant processes by modelling. Freshw. Biol. 36: 249-263.

Uehlinger, U. and M. W. Naegeli, 1998. Ecosystem metabolism, disturbance, and stability in a prealpine gravel bed river. J. N Am. Benthol. Soc. 17: 165-178.

Uehlinger, U., M. W. Naegeli and S. G. Fisher, 2002. A heterotrophic desert stream? The role of sediment stability. Western North American Naturalist 62: 466-473.

USEPA 1985. Ambient water quality criteria for ammonia -1984 , Washington, D.C

Weber, C. I., 1973. Recent developments in the measurements of the response of plankton and periphyton to changes in their environment. In: G. E. Glass (ed.), Bioassay techniques and environmental chemistry. Ann Arbor Scientific Publication, Ann Arbor. pp. 119-138.

Welch, E. B., J. M. Jacoby, R. R. Horner and M. R. Seeley, 1988. Nuisance biomass levels of periphytic algae in streams. Hydrobiol. 157: 161-168.

Whittaker, R. H. and G. E. Likens, 1975. The biosphere and man. In: H. Lieth and R. H. Whittaker (ed.), Primary productivitiy of the biosphere. Springer, Berlin. pp. 305-328.

Wuhrmann, K. and E. Eichenberger, 1975. Experiments on the effects of inorganic enrichments of rivers on periphyton primary production. Verh. Int. Ver. Limnol. 19: 2028-2034.

Zar, J. H., 1984. Biostatistical analysis. Prentice Hall, Englewood Cliffs, New Jersey.
To access this journal online: $h t t p: / / w w w . b i r k h a u s e r . c h$ 